\title{
Cell cycle-specific association of E2F with the p130 E1A-binding protein
}

\author{
David Cobrinik, ${ }^{1}$ Peter Whyte, ${ }^{2}$ Daniel S. Peeper, ${ }^{3}$ Tyler Jacks, ${ }^{4,5}$ and Robert A. Weinberg ${ }^{1,5,6}$ \\ ${ }^{1}$ Whitehead Institute for Biomedical Research, Cambridge Massachusetts 02142 USA; ${ }^{2}$ Institute for Molecular Biology \\ and Biotechnology, McMaster University, Hamilton, Ontario, Canada L8S 4K1; ${ }^{3}$ Department of Molecular Carcinogenesis, \\ Sylvius Laboratory, University of Leiden, 2333 AL Leiden, The Netherlands; ${ }^{4}$ Center for Cancer Research and ${ }^{5}$ Department \\ of Biology, Massachusetts Institute of Technology, Cambridge Massachusetts 02142 USA
}

Association of the E2F transcription factor with the $\mathrm{pRb}$ and $\mathrm{p} 107$ proteins appears to regulate the activity of E2F and, in turn, affect cell cycle progression. We found, however, that pRb and p107 are only minor E2F-associated proteins in $G_{0} / G_{1}$ mouse fibroblasts, and we sought to identify the major E2F partner protein in these cells. Because the adenovirus E1A oncoprotein seemed able to bind to the $G_{0}$ E2F partner, we enriched for proteins that associated both with an E2F-binding site DNA column and with E1A. The major species in $G_{0}$ and early $G_{1}$ fibroblasts detected with this approach had properties identical to the $p R b$ - and p107-related p130 protein. In serum-stimulated cells, p107 replaced p130 as the major E2F-associated protein near the $G_{1} / S$ border, concomitant with an increase in p107 protein levels. p130-E2F complexes resembled p107-E2F complexes in their ability to bind to cyclin-cdk kinases, and they appeared to be associated with the cyclin $E-c d k 2$ kinase in late $G_{1}$ cells. These observations indicate that E2F transcription factors are regulated by a succession of partner proteins with which they associate during defined stages of the cell cycle.

[Key words: Cell cycle; E2F; E1A; p130; pRb; p107]

Received August 13, 1993; revised version accepted September 10, 1993.

E2F transcription factors are required for the regulation of a number of genes involved in cell growth control. Known E2F-responsive genes, as well as other genes with promoter E2F sites, are induced when resting $\mathrm{G}_{0}$ cells are stimulated to reenter the cell cycle (Blake and Azizkhan 1989; Hiebert et al. 1989; Thalmeier et al. 1989; Dalton 1992; Nevins 1992; Lam and Watson 1993). Some E2Fresponsive genes, such as c-myc, are induced during the transition from $G_{0}$ to $G_{1}$, whereas others, such as dihydrofolate reductase, are induced near the $\mathrm{G}_{1} / \mathrm{S}$ border (Kelly et al. 1983; Farnham and Schimke 1985). Modulation of E2F function may ensure the appropriate expression of these genes during specific phases of the cell growth cycle.

The sequence-specific DNA-binding activity known as E2F consists of a group of cellular proteins, including E2F-1 and DP-1, that appear to bind as heterodimers to E2F sites in various promoters (Helin et al. 1992, 1993; Kaelin et al. 1992; Girling et al. 1993; Huber et al. 1993; Lees et al. 1993). The function of these E2Fs may be regulated in turn by their cell cycle-specific association with yet other proteins. For example, some E2Fs associate with the hypophosphorylated form of the retinoblastoma protein $(\mathrm{pRb})$ found in the $\mathrm{G}_{0}$ and $\mathrm{G}_{1}$ phases of the cell cycle but do not associate with hyperphosphorylated $\mathrm{ppRb}$ found in the $S, G_{2}$, and $M$ phases of this cycle

${ }^{6}$ Corresponding author.
(Buchkovich et al. 1989; Chen et al. 1989; DeCaprio et al. 1989; Chellappan et al. 1991; Mittnacht and Weinberg 1991). In cells transfected with $\mathrm{pRb}$ expression vectors, $\mathrm{pRb}$ inhibits the expression of E2F-dependent genes (Hamel et al. 1992; Hiebert et al. 1992; Weintraub et al. 1992; Zamanian and LaThangue 1992), suggesting that E2F binding is a mechanism used by $\mathrm{pRb}$ to regulate cell cycle progression.

E2Fs have also been found in association with the pRbrelated p107 protein (Ewen et al. 1991; Mudryi et al. 1991; Cao et al. 1992; Devoto et al. 1992; Shirodkar et al. 1992) and have been postulated to bind a third protein distinct from $\mathrm{pRb}$ and P107 (Chittenden et al. 1993). Like pRb, pl07 also inhibits E2F-dependent gene expression (Schwartz et al. 1993; Zamanian and La Thange 1993; Zhu et al. 1993). The E2F species that complex with pl07, however, may be distinct from those that complex with pRb (Dyson et al. 1993). p107-containing E2F complexes are first readily detected near the $G_{1} / S$ border and also contain cyclin E-cdk2 or cyclin A-cdk2 kinases (Cao et al. 1992; Devoto et al. 1992; Lees et al. 1992; Pagano et al. 1992; Shirodkar et al. 1992). Thus, the different E2Fs may be controlled by specific $\mathrm{pRb}$-related protein regulators at distinct points in the cell cycle.

The interactions between E2Fs and their associated proteins can be disrupted by adenovirus E1A and other DNA tumor virus oncoproteins that bind $\mathrm{pRb}$ and $\mathrm{p} 107$ and block their ability to associate with E2Fs (Bagchi et al. 1990, 1991; Chellappan et al. 1991, 1992; Mudryi et 
al. 1991; Shirodkar et al. 1992; Chittenden et al. 1993). In effect, these oncoproteins liberate E2Fs from $\mathrm{pRb} / \mathrm{p} 107$ control and in this way promote the expression of E2Fdependent genes (Hamel et al. 1992; Hiebert et al. 1992; Weintraub et al. 1992; Zamanian and LaThangue 1992, 1993; Schwarz et al. 1993).

To elucidate the role of E2Fs in cell cycle control, we have sought to identify the components of E2F-containing complexes that form at various points in the cell cycle. In the course of this work, we detected a novel E2F-containing complex that is present in the $G_{0}$ and $G_{1}$ cell cycle phases and identified an E2F-associated protein present in this complex. We explore the implications of the existence of this E2F complex for the control of E2F activity during cell cycle progression.

\section{Results}

\section{Association of E2F with other proteins in $G_{0}$}

In our initial experiments, we utilized a mobility shift assay to detect E2Fs and E2F-containing protein complexes through their ability to bind and retard the migration of a radiolabeled oligonucleotide containing an E2Fbinding site.

Two distinct E2F-containing complexes were detected in serum-starved mouse embryo fibroblasts (MEFs; Fig. 1, lane 4). Both complexes were specific for the E2F-binding DNA sequence because their binding to a ${ }^{32}$ p-labeled c-myc promoter E2F site was reduced by the addition of excess unlabeled oligonucleotide containing the two adenovirus E2 promoter E2F sites but not by an equal amount of a similar oligonucleotide having E2F site point mutations (lanes 4-6).

The faster migrating DNA-protein complex appeared to contain only free E2F because it comigrated with a complex formed by free E2F purified from HeLa cells (lanes 1,4 ). The second more slowly migrating complex appeared to contain E2F in association with another protein because this complex was disrupted upon incubation of the extract with either deoxycholate or E1A /data not shown), as observed previously for $\mathrm{G}_{0}$ E2F complexes found in NIH-3T3 fibroblasts (Mudryj et al. 1991).

The behavior of the slowly migrating E2F complex in response to deoxycholate and E1A was reminiscent of $\mathrm{pRb}-\mathrm{E} 2 \mathrm{~F}$ complexes characterized by others (Chellappan et al. 1991; Shirodkar et al. 1992). To determine whether $p R b$ is a component of the $G_{0} E 2 F$ complex, wild-type MEF E2F complexes were compared with those of $R b^{-}$ MEFs, the latter having been prepared from mouse embryos that had inherited two inactivated $R b$ gene copies (Jacks et al. 1992). The normal and $R b^{-} M_{E F} G_{0}$ extracts contained identically migrating E2F complexes (lanes 4,8-10), indicating that such complexes do not contain $\mathrm{pRb}$ as a major component.

Yet other evidence distinguished the slowly migrating MEF $G_{0} E 2 F$ complex from pRb-E2F complexes. Thus, the $G_{0}$ E2F complex migrated more slowly than $p R b-E 2 F$ complexes formed in extracts of mouse splenic lympho-

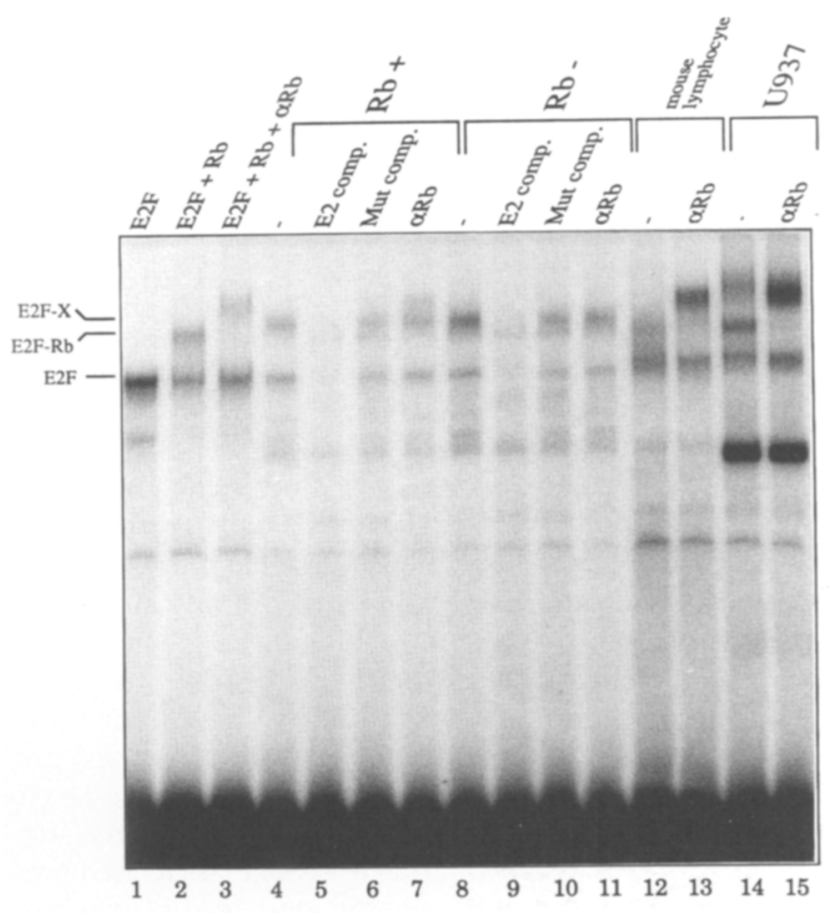

Figure 1. Characterization of E2F-containing complexes in $\mathrm{G}_{0}$ MEFs. Extracts of wild-type (lanes 4-7) and $R b^{-}$(lanes 8-11) MEFs were incubated with a ${ }^{32} \mathrm{P}$-labeled $\mathrm{c}-\mathrm{myc}$ promoter E2F site and subjected to gel electrophoresis. Reactions included a 20 -fold excess of unlabeled oligonucleotide containing the adenovirus E2 promoter E2F sites (lanes 5,9) or point-mutated E2F sites (lanes 6,10), or the $21 \mathrm{C} 9 \mathrm{pRb}$ antibody (lanes 7,11). Mobility shifts were also performed with affinity-purified HeLa cell E2F in the absence (lane 1) or presence (lanes 2,3) of affinitypurified $\mathrm{pRb}$, and with nuclear extracts of primary mouse splenic lymphocytes (lanes 12,13) and U937 monocytes (lanes 14,15 ), with $21 \mathrm{C} 9 \mathrm{pRb}$ antibody added as indicated (lanes 3,13 , 15). The locations of free E2F, E2F-pRb complexes, and unidentified E2F-X complexes are indicated. All incubations included $0.4 \mathrm{mM}$ spermine to facilitate detection of $\mathrm{pRb}-\mathrm{E} 2 \mathrm{~F}$ complexes.

cytes and human U937 monocytes (lanes $8,12,14$ ). The presence of $\mathrm{pRb}$ in the lymphocyte and monocyte complexes could be verified by the fact that their migration was retarded (i.e., supershifted) by a $\mathrm{pRb}$ monoclonal antibody (lanes 12-15). The MEF $\mathrm{G}_{0}$ complex also migrated more slowly than $\mathrm{pRb}-\mathrm{E} 2 \mathrm{~F}$ complexes formed in vitro by mixing purified HeLa cell E2F with purified pRb (lanes $1-4)$.

Although the great majority of the E2F-containing complexes in the $R b^{+}$cell extracts appeared to lack $\mathrm{pRb}$, a small amount of pRb-E2F complex could be detected in these cell extracts. Thus, a novel mobility shift complex was observed when $R b^{+}$MEF extracts, but not $R b^{-}$ MEF extracts, were incubated with $\mathrm{pRb}$ antibody (lanes 7,11 ). These results indicate that $\mathrm{pRb}$ is a minor component of E2F complexes in serum-starved MEFs.

Complexes of E2F with p107 in $G_{0}$ and $G_{1}$

Besides pRb, the other well-characterized E2F-binding protein in the cell is p107, which has been shown to 
complex with E2F in the late $G_{1}$ and $S$ phases of the cell cycle (Lees et al. 1992; Shirodkar et al. 1992; Schwarz et al. 1993). To test whether the observed $G_{0}$ complexes might contain p107, the MEF extracts described above and control extracts from S-phase cells were incubated with p107 antibodies (generously provided by M. Dembski and N. Dyson).

In preliminary experiments, saturating amounts of a purified p107 monoclonal antibody supershifted only a small fraction of the $G_{0}$ E2F complexes, whereas it supershifted nearly all of the S-phase E2F complexes (data not shown). The supershifted complexes induced by p107 antibody bound specifically to the oligonucleotide E2F site because they were not detected in the presence of excess E2F site-containing oligonucleotide (data not shown). In addition, a p107 polyclonal mouse antiserum had no detectable effect on $\mathrm{G}_{0}$ complexes, but it abolished S-phase E2F complexes. The mouse antiserum probably recognizes different p107 epitopes than the monoclonal antibody because it disrupted but did not effectively supershift most p107-containing S-phase complexes (data not shown). These experiments suggested that $\mathrm{p} 107$ is not the major $\mathrm{G}_{0}$ E2F-associated protein. Further experiments used the more readily synchronized A31 BALB/c 3T3 cell line to explore when p107 does become the major E2F partner during cell cycle progression.

A31 cell extracts were prepared $0,3,7,11$, and $15 \mathrm{hr}$ after serum stimulation of quiescent A31 cells and used for mobility shift assays (Fig. 2). Whereas the mobility of E2F complexes was unchanged from 0 to $7 \mathrm{hr}$, a more slowly migrating complex was first detected in the extracts prepared at $11 \mathrm{hr}$ and this complex became prominent at $15 \mathrm{hr}$ (lanes 1-5), as the first cohort of these cells (5\% of the total) passed from $G_{1}$ into $S$ phase (as determined by flow cytometry analysis; data not shown). Addition of saturating amounts of pl07 monoclonal antibody to extracts prepared at the 0 - to $11-\mathrm{hr}$ time points caused $10-15 \%$ of the E2F complexes to supershift while causing $\sim 70 \%$ of the complexes isolated from cells at 15 $\mathrm{hr}$ postserum stimulation to supershift (Fig. 2, lanes 6-10). Thus, p107 appears to become the major E2F partner only as these mouse fibroblasts approach the $G_{1} / S$ border.

\section{Biochemical identification of E2F-associated proteins in extracts of $G_{0} / G_{1}$ mouse fibroblasts}

We concluded from the above experiments that neither pRb nor p107 is the major E2F-associated protein in $G_{0}$ and $G_{1}$ mouse fibroblasts and sought to identify the apparently novel $G_{0} / G_{1} E 2 F$ partner. The ability of the adenovirus E1A protein to dissociate mouse fibroblast $G_{0} /$ $\mathrm{G}_{1}$ E2F complexes (Mudryi et al. 1991; D. Cobrinik, data not shown/ suggested that E1A binds to the $G_{0} / G_{1}$ E2F partner in the same way that E1A binds to $\mathrm{pRb}$ or p107. For this reason, we designed a strategy to purify this E2F-associated protein that relied on its predicted affinity for both E2F and E1A.

In detail, the enrichment of the E2F partner involved

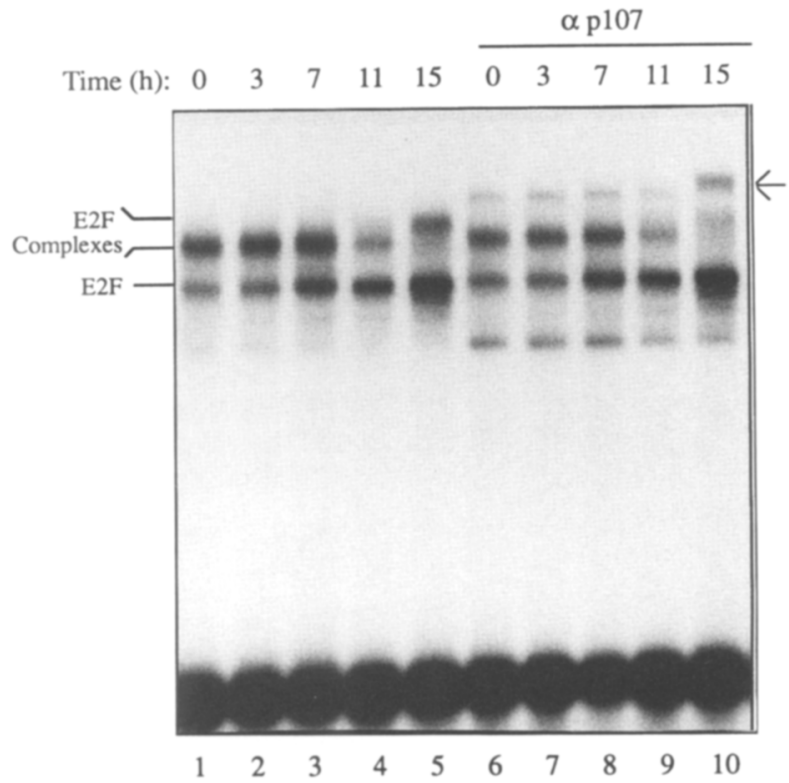

Figure 2. Detection of $\mathrm{G}_{0}$ and $\mathrm{G}_{1}$ E2F complexes that do not contain p107. Extracts were prepared from A31 cells following serum starvation (lanes 1,6$)$ or $3,7,11$, or $15 \mathrm{hr}$ after serum stimulation (lanes $2-5,7-10$ ) and subjected to mobility shift analysis in the absence (lanes 1-5) or presence (lanes 6-10) of SD-15 pl07 antibody. The positions of free E2F, E2F complexes, and p107 antibody-dependent supershift complexes (arrow) are indicated. Cells used for this experiment were metabolically labeled with $\left[{ }^{35} \mathrm{~S}\right]$ methionine, and the ${ }^{35} \mathrm{~S}$ signal was blocked by autoradiography film.

an initial chromatography of metabolically labeled proteins from serum-starved A31 cells over a herring sperm DNA column, followed by chromatography of this column's flowthrough fraction over an oligonucleotide column containing adenovirus E2 promoter sequences that bind E2F. Complexes adsorbing to these columns were eluted in high ionic strength buffer and mixed with E1A oncoprotein prepared from baculovirus-infected insect cells (Peeper et al. 1992). These mixtures were then immunoprecipitated with ElA antibody, and the proteins that coimmunoprecipitated with E1A were separated by SDS-PAGE. This strategy allows the detection of E1Abinding proteins that associate with any of the E2F-like proteins that can adhere to the E2 promoter E2F sites.

As shown in the mobility shift assays in Figure 3A, free and complexed E2F largely passed through the herring sperm DNA column but both forms of E2F were retained on the E2 oligonucleotide column. E2F DNAbinding activity was eluted from the E2 column as free E2F (lane 9), probably because of the disruption of the E2F complexes by the high ionic strength elution buffer.

Equal amounts of radiolabeled protein from the DNA and E2 affinity column eluates were then mixed with E1A or control insect cell lysates and immunoprecipitated with E1A antibody (Fig. 3B). Minor proteins of $\sim 105$ and $115 \mathrm{kD}$ and a major protein of $126 \mathrm{kD}$ were detected in the E1A coimmunoprecipitation of the E2 


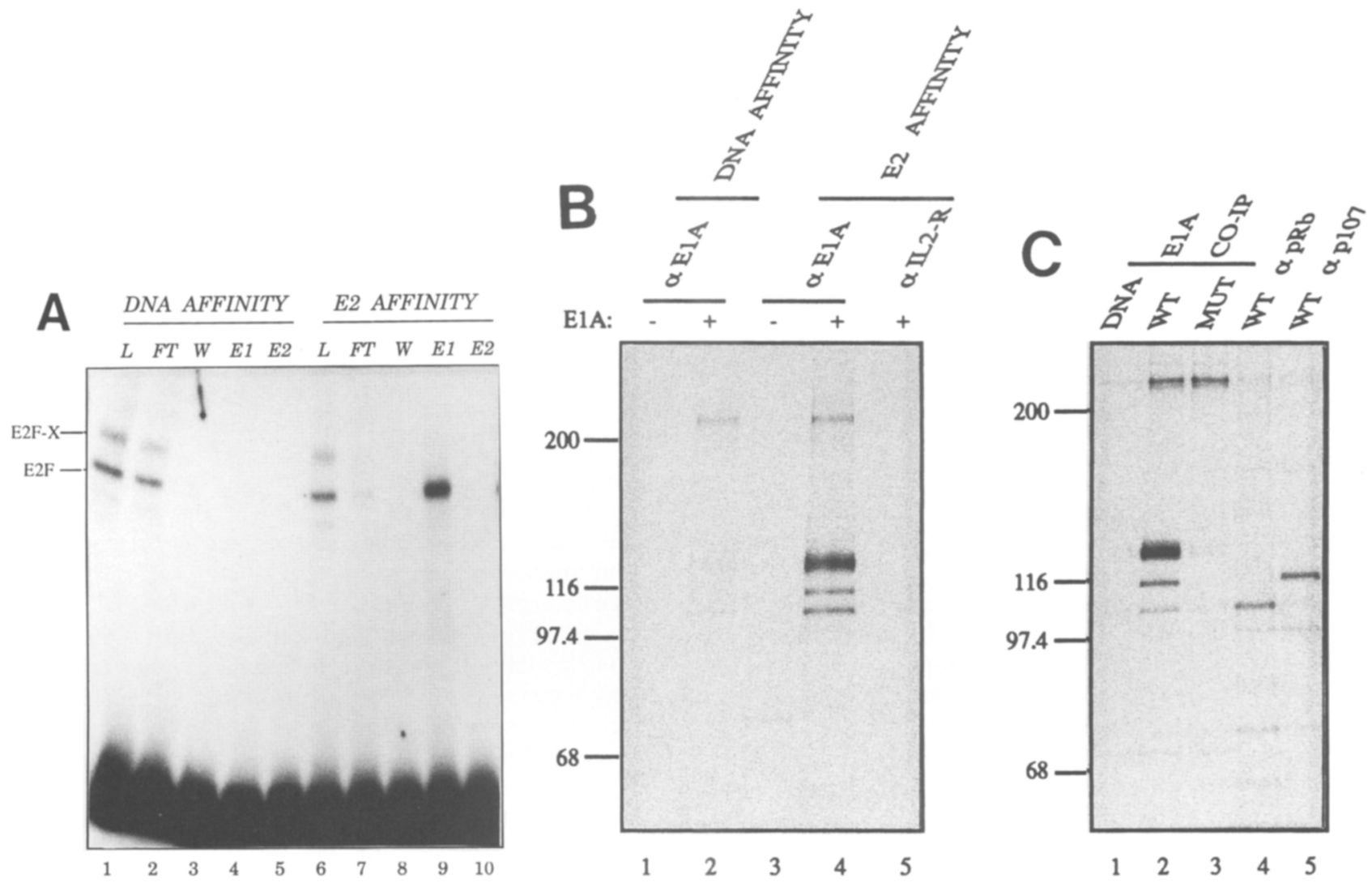

Figure 3. Identification of E2F-associated proteins in $\mathrm{G}_{0}$ mouse fibroblasts using an E2F+E1A affinity enrichment procedure. $(A)$ Mobility shift analysis of A31 fibroblast E2F complexes subjected to chromatography over herring sperm DNA (lanes 1-5) and E2 promoter oligonucleotide (lanes 6-10) columns. The E2F-containing complexes present in the load (L), flowthrough (FT), wash (W), and elution (E) fractions are displayed. Cells used for this experiment were metabolically labeled with $\left[{ }^{35} S \mid m e t h i o n i n e\right.$, and the ${ }^{35} S$ signal was blocked by autoradiography film. $(B)$ E1A coimmunoprecipitation of proteins eluted from herring sperm DNA (lanes 1,2) and E2 promoter oligonucleotide (lanes 3-5) columns. Equal amounts of radiolabeled proteins were mixed with lysates of wild-type (lanes 1,3) or E1A-expressing (lanes 2,4,5) baculovirus-infected cells, and the mixture was immunoprecipitated with anti-ElA (lanes 1-4) or anti-IL2-receptor (lane 5) antibodies. (C) Detection of pRb, pl07, and p126. Equal amounts of radiolabeled proteins eluted from herring sperm DNA (lane 1), wild-type E2F site (lanes 2,4,5), or point-mutated E2F site (lane 3) columns either were mixed with lysates of ElA-expressing baculovirus-infected cells and immunoprecipitated with ElA antibody (lanes 1-3), or were directly immunoprecipitated with pRb (lane 4) or pl07 (lane 5) antibodies. The positions of molecular mass markers are indicated in kilodaltons.

column eluate (lane 4). These proteins were not detected in the absence of ElA (lane 3) nor were they seen when a control antibody was used (lane 5). Moreover, these proteins were present at far lower levels in an E1A coimmunoprecipitation of the herring sperm DNA column eluate (lane 2). Similar results were obtained with primary MEFs (data not shown). On the basis of these experiments, we concluded that the E2 oligonucleotide column retained a series of proteins that were also able to associate with E1A.

We then tested whether retention of these proteins by the E2 oligonucleotide column depended on the presence of the E2F recognition sequence. Thus, E2F complexes that flowed through the herring sperm DNA column were chromatographed subsequently over columns consisting of either an E2 promoter E2F recognition sequence oligonucleotide or a point-mutated version thereof that is not bound effectively by E2F (Hiebert et al. 1989). Following coimmunoprecipitation of the proteins eluted from these columns in the presence of E1A, we found that the 105-, 115-, and 126-kD species were efficiently retained by the wild-type oligonucleotide column but were not retained by the column bearing the mutant oligonucleotide or by the herring sperm DNA column (Fig. 3C, lanes 1-3). We concluded that these species associate with proteins that have the identical DNA recognition sequence as E2F transcription factors.

The electrophoretic mobilities of the two more rapidly migrating E2F + E1A-associated proteins were reminiscent of those ascribed to $\mathrm{pRb}$ and $\mathrm{p} 107$. To determine whether these E2F-associated proteins were $\mathrm{pRb}$ and p107, the eluate of the wild-type E2F site column was immunoprecipitated with $\mathrm{pRb}$ and $\mathrm{p} 107$ antibodies. $\mathrm{pRb}$ antibody immunoprecipitated a $105-\mathrm{kD}$ protein that comigrated with the E2F+E1A-associated $105-\mathrm{kD}$ protein (Fig. 3C, lane 4), whereas p107 antibody immuno- 
precipitated a $115-\mathrm{kD}$ protein that comigrated with the $\mathrm{E} 2 \mathrm{~F}+\mathrm{E} 1 \mathrm{~A}$-associated $115-\mathrm{kD}$ protein (Fig. 3C, lane 5). Thus, E2F is associated with pRb, p107, and a third predominant partner protein-provisionally termed p126in $\mathrm{G}_{0}$ mouse fibroblast extracts.

\section{Relationship between 126 and the E1A-associated p130 protein}

The apparent size of p126 was similar to that of the E1Aassociated p130 protein detected by virtue of its ability to be coimmunoprecipited with E1A from lysates of adenovirus-transformed human embryonic kidney 293 cells (Harlow et al. 1986). A series of experiments comparing the electrophoretic migration rates, phosphatase sensitivities, antibody reactivities, and proteolytic peptide maps of the two proteins led us to believe that p126 was a modified form of this pl30. These experiments utilized human cells, instead of the mouse fibroblasts used earlier, to control for any species-specific size or sequence differences.

We first compared the electrophoretic migration of 293 cell p130 to that of E2F + E1A-associated proteins in several human cell types (Fig. 4). A 126-kD E2F+E1Aassociated protein detected in serum-starved human $\mathrm{SiFt}$ fibroblasts comigrated with mouse fibroblast p126 (data not shown) but migrated more rapidly than 293 cell pl30 (lanes 1,2). In contrast, distinct E2F+ElA-associated proteins comigrated with both p126 and p130 in serumstarved human $\mathrm{HaCaT}$ keratinocytes and embryonic kidney (HEK) and retinal (HER) cells (lanes 3-5). Like pRb and p107, the 126- and $130-\mathrm{kD}$ proteins required ElA for their coimmunoprecipitation with E1A antibody (lanes 6-9) and were more effectively retained on the E2 column than on the herring sperm DNA column (lanes 1013). Each of these proteins was also retained on the wildtype but not the point-mutated E2F site column /data not shown|. Thus, in addition to p126, an ElA-binding pro- tein identical in size to p130 associates with E2F in certain cell types.

We then tested whether p130 and the E2F + E1A-associated $126-$ and $130-\mathrm{kD}$ species might be differentially phosphorylated forms of the same protein. ${ }^{35} \mathrm{~S}$-Labeled cellular E2F + E1A-associated proteins and 293 cell E1Aassociated proteins were treated with potato acid phosphatase or with phosphatase buffer before electrophoresis (Fig. 5A). Phosphatase converted the 293 cell pl30 and the HEK, HER, and $\mathrm{HaCaT}$ cell $130-\mathrm{kD}$ protein bands to $126-\mathrm{kD}$ species (lanes $1,2,5,6$; data not shown), whereas sodium phosphate, an inhibitor of this phosphatase, prevented these conversions (data not shown). Phosphatase treatment also caused a modest narrowing of the $\mathrm{SiFt} 126-\mathrm{kD}$ protein band that comigrates with phosphatase-treated p130 (lanes 3,4 ). These results support the view that p130 and the E2F+E1A-associated $126-$ and $130-\mathrm{kD}$ species are differentially phosphorylated forms of the same protein.

To determine whether the 126- and 130-kD E2F + E1Aassociated proteins are both recognized by a pl30 antibody, ${ }^{35}$ S-labeled $\mathrm{HaCaT}$ cell E2F + E1A-associated proteins were separated by electrophoresis, transferred to nitrocellulose, and either probed with p130 antibody or detected directly by autoradiography (Fig. 5B). The p130 antibody recognized $126-$ and $130-\mathrm{kD}$ proteins, as well as the pl07 protein with which it cross-reacts ( $\mathrm{Li}$ et al. 1993), in anti-E1 A immunoprecipitates of the E2 column eluate performed in the presence but not in the absence of E1A (lanes 2,3). This antibody failed to recognize such proteins in immunoprecipitates of the herring sperm DNA column eluate (lane 1). The $126-$ and $130-\mathrm{kD}$ proteins recognized by the pl30 antibody comigrated with ${ }^{35}$ S-labeled E2F + E1A-associated proteins that had been transferred to the same membrane (lane 5), and the 130$\mathrm{kD}$ protein was largely converted to $126-\mathrm{kD}$ by phosphatase treatment (lane 4). The recognition of both the 126- and $130-\mathrm{kD}$ E2F + E1A-associated proteins by p130
Figure 4. Comparison of cellular E2F + E1A-associated proteins with 293 cell E1A-associated proteins. Whole cell extracts prepared from metabolically labeled serum-starved human SiFt fibroblasts, HaCaT keratinocytes, HEK, or HER cells were subjected to chromatography over herring sperm DNA (lanes 10-13) and E2 promoter oligonucleotide (lanes 2-9) columns. Equal amounts of radiolabeled proteins eluted from these columns were mixed with lysates of ElA-expressing (lanes 2-5,10-13) or wild-type (lanes 6-9) baculovirus-infected cells, and the mixtures were immunoprecipitated with ElA antibody. Lane 1 displays metabolically labeled 293 cell proteins coimmunoprecipitated with E1A antibody. The pRb, p107, p130, and p300 species and the positions of molecular mass markers are indicated.

P

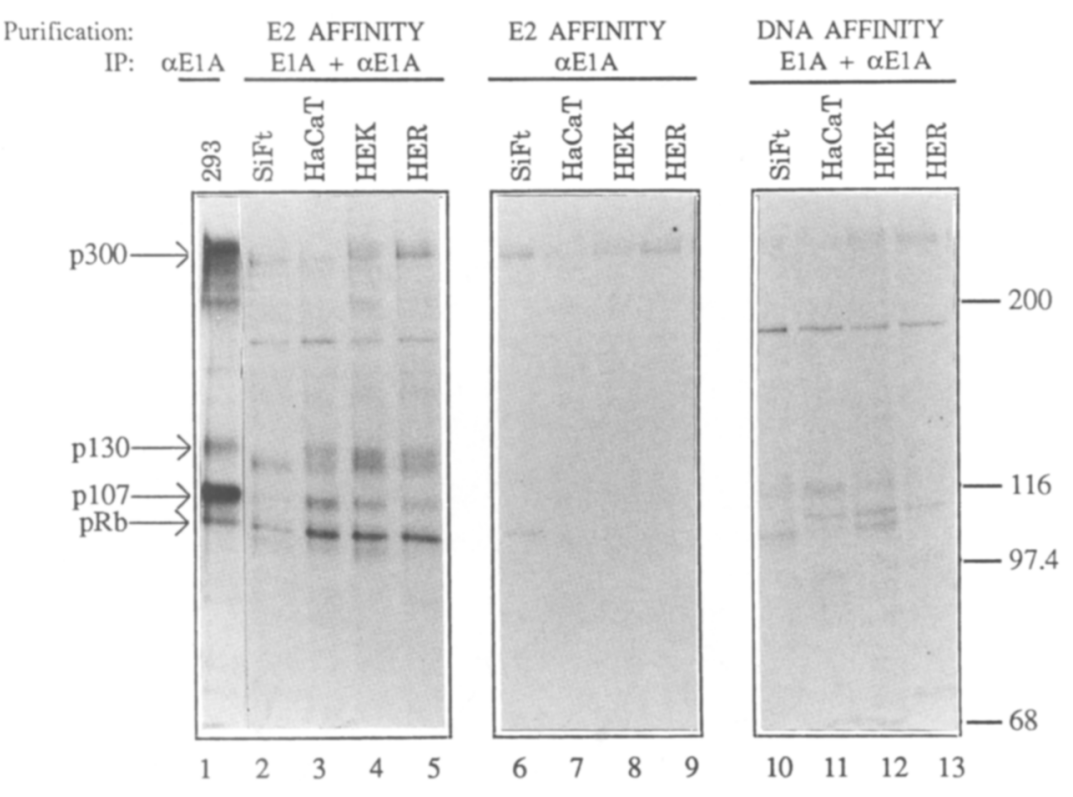




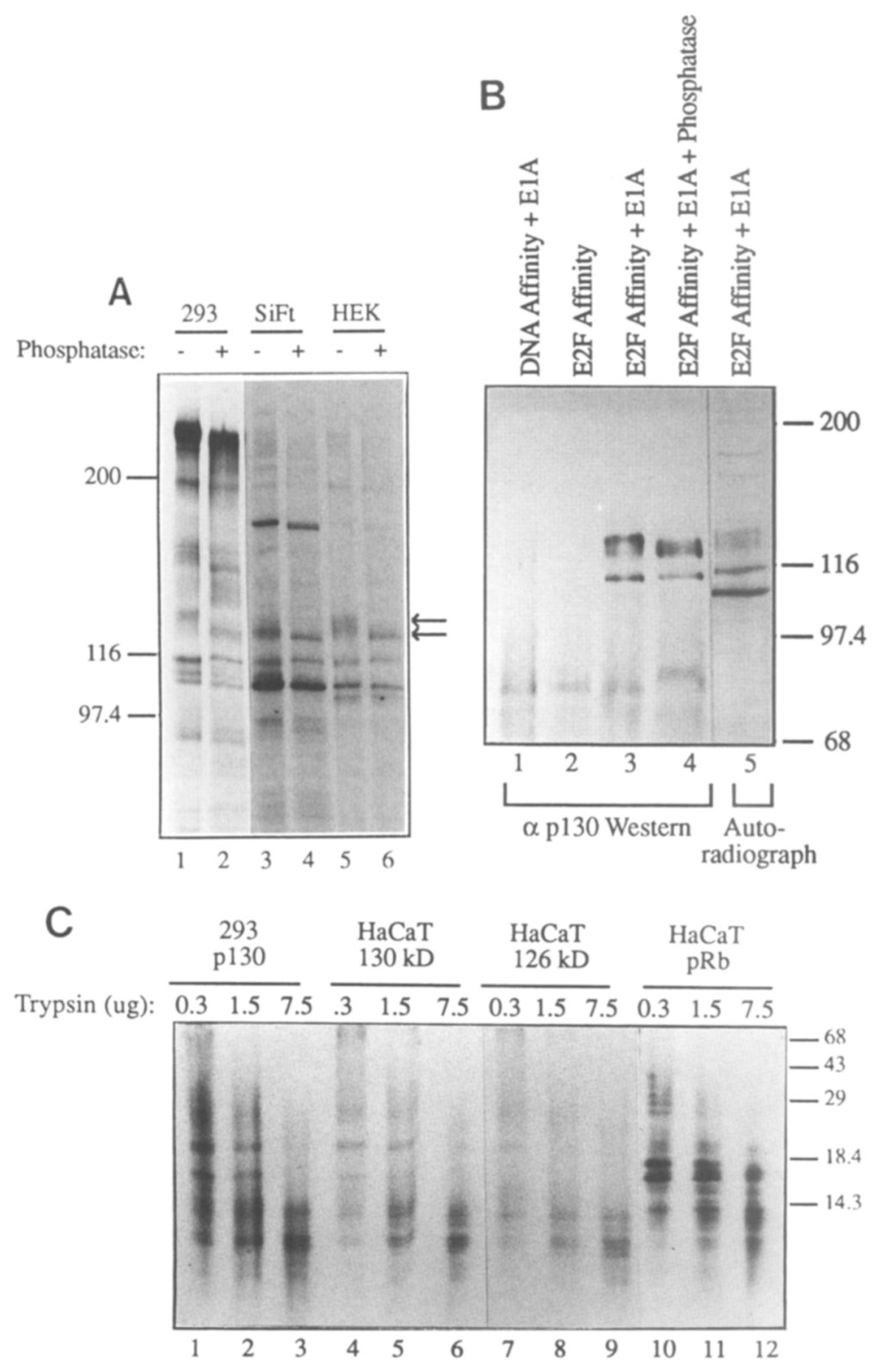

Figure 5. Relationship between pl30 and the 126and 130-kD E2F + E1A-associated proteins. $(A)$ Phosphatase sensitivity. Metabolically labeled 293 cell E1A-associated proteins (lanes 1,2) and SiFt (lanes $3,4)$ and HEK (lanes 5,6) E2F + E1A-associated proteins were treated with potato acid phosphatase (lanes $2,4,6$ ) or phosphatase buffer (lanes $1,3,5$ ) before electrophoresis. The 126- and 130-kD E2F+E1A-associated proteins (arrows) and the positions of molecular mass markers are indicated. $(B)$ Recognition of the E2F+E1A-associated $126-$ and $130-\mathrm{kD}$ proteins by pl30 antibody. Extracts of serum-starved $\mathrm{HaCaT}$ cells were subjected to chromatography over herring sperm DNA (lane 1) and E2 promoter oligonucleotide (lanes 2-5) columns. Equal amounts of radiolabeled proteins eluted from these columns were mixed with lysates of E1A-expressing (lanes $1,3,4,5)$ or wild-type (lane 2) baculovirus-infected cells, the mixtures were immunoprecipitated with E1A antibody, and the immunoprecipitates were incubated with potato acid phosphatase (lane 4) or phosphatase buffer (lanes 1-3,5). Proteins were separated by polyacrylamide gel electrophoresis and transferred to a nitrocellulose membrane that was then subjected either to Western blotting with a p130 monoclonal antibody (lanes 1-4) or to autoradiography (lane 5). The positions of molecular mass markers are indicated. $(C)$ Peptide maps of p130 and the E2F + E1A-associated 130- and $126 \mathrm{kD}$-proteins. 293 cell E1A-associated proteins and $\mathrm{HaCaT}$ cell $\mathrm{E} 2 \mathrm{~F}+\mathrm{E} 1 \mathrm{~A}$-associated proteins were separated by polyacrylamide gel electrophoresis, and gel slices containing 293 cell p130 (lanes 1-3) and $\mathrm{HaCaT}$ cell $130-\mathrm{kD}$ (lanes 4-6) and 126-kD (lanes 7-9) proteins were incubated with $0.3,1.5$, or $7.5 \mu \mathrm{g}$ of a crude trypsin preparation as indicated. Similarly treated $\mathrm{pRb}$ is shown as a control (lanes 10-12). The positions of molecular mass markers are indicated in kilodaltons. antibody supports the notion that these species are differentially phosphorylated forms of $\mathrm{p} 130$.

The relatedness of the 126- and 130-kD E2F-associated proteins and p130 was solidified by comparing the sizes of proteolytic digestion products of these species. The peptide maps produced by the digestion of $\mathrm{HaCaT}$ cell 126- and 130-kD E2F+E1A-associated proteins with a crude trypsin preparation were identical to those of 293 cell p130 but differed from a map of pRb included as a control (Fig. 5C). These experiments show conclusively that two differentially phosphorylated forms of the previously identified p130 ElA-binding protein associate with E2F transcription factors.

\section{Cell cycle-dependent association of E2F with p130}

The E2F + E1A affinity purification scheme described above was used to survey the changing spectrum of E2F partners as the cell moves from $G_{0}$ through $G_{1}$ and into $S$. For this experiment, we analyzed the extracts from serum-starved and restimulated A31 cells that had been used in the study described in Figure 2. These extracts had been labeled with $\left[{ }^{35} S\right]$ methionine, either for $4 \mathrm{hr}$ before restimulation, in the case of the $G_{0}$ preparation, or for the final $2 \mathrm{hr}$ of each of the restimulation periods.

The faster migrating form of p130 was the major E2F + E1A-associated species labeled in $\mathrm{G}_{0}$ and $3 \mathrm{hr}$ after serum stimulation, whereas p107 became the major E2F partner detected as the cells approached the $\mathrm{G}_{1} / \mathrm{S}$ border 11-15 hr after serum stimulation (Fig. 6A, lanes 1-6). Although the E2F+E1A-associated p130 appeared to be reduced $7 \mathrm{hr}$ after serum stimulation, pl30 is likely to continue to be the major E2F partner detected by mobility shift analysis at this time (see Fig. 2), because only 

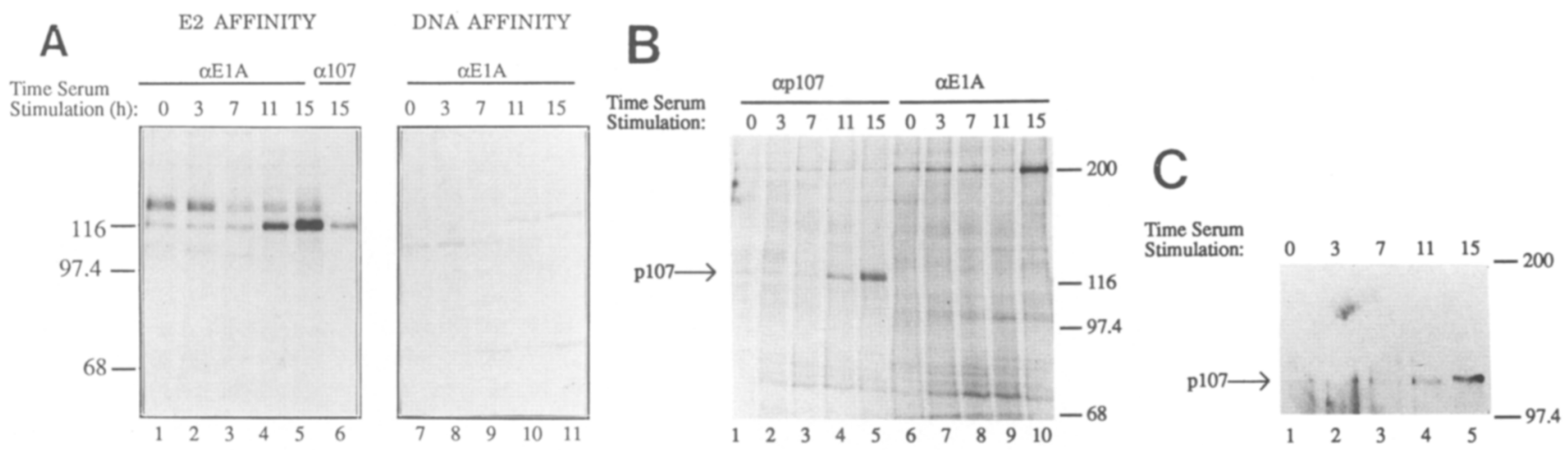

Figure 6. Cell cycle-dependent association of E2F with p130 and p107. (A) Transitions between E2F-associated proteins in A31 cells. Metabolically labeled A31 cell proteins were subjected to chromatography over herring sperm DNA (lanes 7-11) and E2 promoter oligonucleotide (lanes 1-6) columns, and equal amounts of radiolabeled proteins eluted from these columns were coimmunoprecipitated with E1A. A31 cells were serum starved (lanes 1,7) or restimulated for 3, 7, 11, or $15 \mathrm{hr}$ as indicated (lanes 2-5,8-11). The eluate of the $\mathrm{E} 2$ promoter oligonucleotide column corresponding to $15 \mathrm{hr}$ serum-stimulated cells was also directly immunoprecipitated with p107 antibody (lane 6). The positions of molecular mass markers are indicated in kilodaltons. (B) Induction of p107 synthesis in serum-stimulated A31 cells. Equal amounts of radiolabeled protein prepared from metabolically labeled serum-starved (lanes 1-6) or restimulated (lanes 2-5,7-10) cells were immunoprecipitated with anti-p107 (lanes 1-5) or anti-ElA control (lanes 6-10) antibodies. (C) Induction of p107 protein levels in serum-stimulated A31 cells. Equal amounts of protein prepared from serum-starved (lane 1) or restimulated (lanes 2-5) cells were immunoprecipitated with p107 antibody, followed by detection of the immunoprecipitated p107 by Western analysis.

newly synthesized p130 is detected with the affinity enrichment procedure. The p130 and p107 proteins detected in these assays were effectively retained on the E2 affinity but not on the herring sperm DNA columns (Fig. $6 \mathrm{~A}$, lanes 7-111. Protein with the approximate migration of $\mathrm{pRb}$ was detected in only small amounts.

Figure 6A shows a dramatic increase in E2F-associated ${ }^{35} \mathrm{~S}$-labeled p107 between 7 and $15 \mathrm{hr}$. This was paralleled by an increase in the quantity of ${ }^{35}$ S-labeled p107 that could be immunoprecipitated from extracts of metabolically labeled A31 cells with p107 antibody (Fig. 6B) and by a similar increase in total p107 levels detected by Western analysis of p107 immunoprecipitates (Fig. 6C). Taken together with the mobility shift assays in Figures 1 and 2, our results indicate that p130 is the major E2Fassociated protein in $G_{0}$ and early $G_{1}$ mouse fibroblasts and that p107 only becomes the major E2F partner when its levels increase near the $G_{1} / S$ border.

\section{Interaction of the mouse fibroblast p130-E2F complex with cyclins and cdks}

Close examination of our initial data revealed that a portion of the E2F complexes detected in late $\mathrm{G}_{1}, 1 \mathrm{hr}$ after serum stimulation, migrated with rates reminiscent of the S-phase E2F-p107-cyclin A-cdk2 complex but appeared to lack p107 (Fig. 2, lanes 4,9). Thus, we speculated that the p130-E2F complexes that predominate in $G_{0}$ and $G_{1}$ cells form higher order complexes with cyclins and their associated kinases in late $G_{1}$. As one test of this possibility, we gauged the ability of cyclins and cdks prepared from baculovirus vector-infected insect cells to interact with MEF $G_{0}$ E2F complexes, which contain p130 as the major E2F-associated protein (Fig. 7A).

Addition of either cyclin E- or cyclin A-containing insect cell lysates retarded the migration of a minority of the $\mathrm{G}_{0}$ E2F complexes, both in the absence and presence of cdc2-containing lysates (lanes 1-3,7-9). The addition of cyclin E- or cyclin A-containing lysates with cdk2containing lysates, however, retarded the migration of nearly all of the $\mathrm{G}_{0}$ E2F complexes (lanes 4,10). Addition of cdk2-containing lysates alone had no effect on the $G_{0}$ E2F complexes (lane 13), whereas uninfected cell lysates or cyclin B-containing lysates in combination with either cdk also failed to retard these complexes (data not shown). The cyclin-cdk2-dependent complexes migrated similarly to p107-containing S-phase complexes, but the majority of these reconstituted complexes appeared to contain $\mathrm{p} 130$, and not p107, because they were not affected by p107 monoclonal antibody or by antip107 mouse serum (data not shown).

The cyclin-cdk2-dependent E2F complexes could be disrupted by the appropriate anti-cyclin antiserum and by cdk2 antibody but not by pre-immune or control antisera (lanes 4-6,10-12,16,17). cdk2 antibody additionally disrupted the complexes formed with $\mathrm{G}_{0}$ extract and cyclin A-containing lysate added alone (lanes 18,19$)$ but had no effect on $G_{0}$ E2F complexes formed in the absence of added proteins (lanes 14,15). Thus, the small amount of the $G_{0}$ complex that could be shifted by the addition of a cyclin (lanes 2,8 ) apparently utilized cdk 2 molecules that were already present in the $G_{0}$ extract.

Together, these data indicated that the $\mathrm{G}_{0}$ E2F-associated protein identified as p130 by the E2F +E1A affinity enrichment procedure is similar to 107 in its ability to bind simultaneously E2F and a cyclin-kinase complex. 

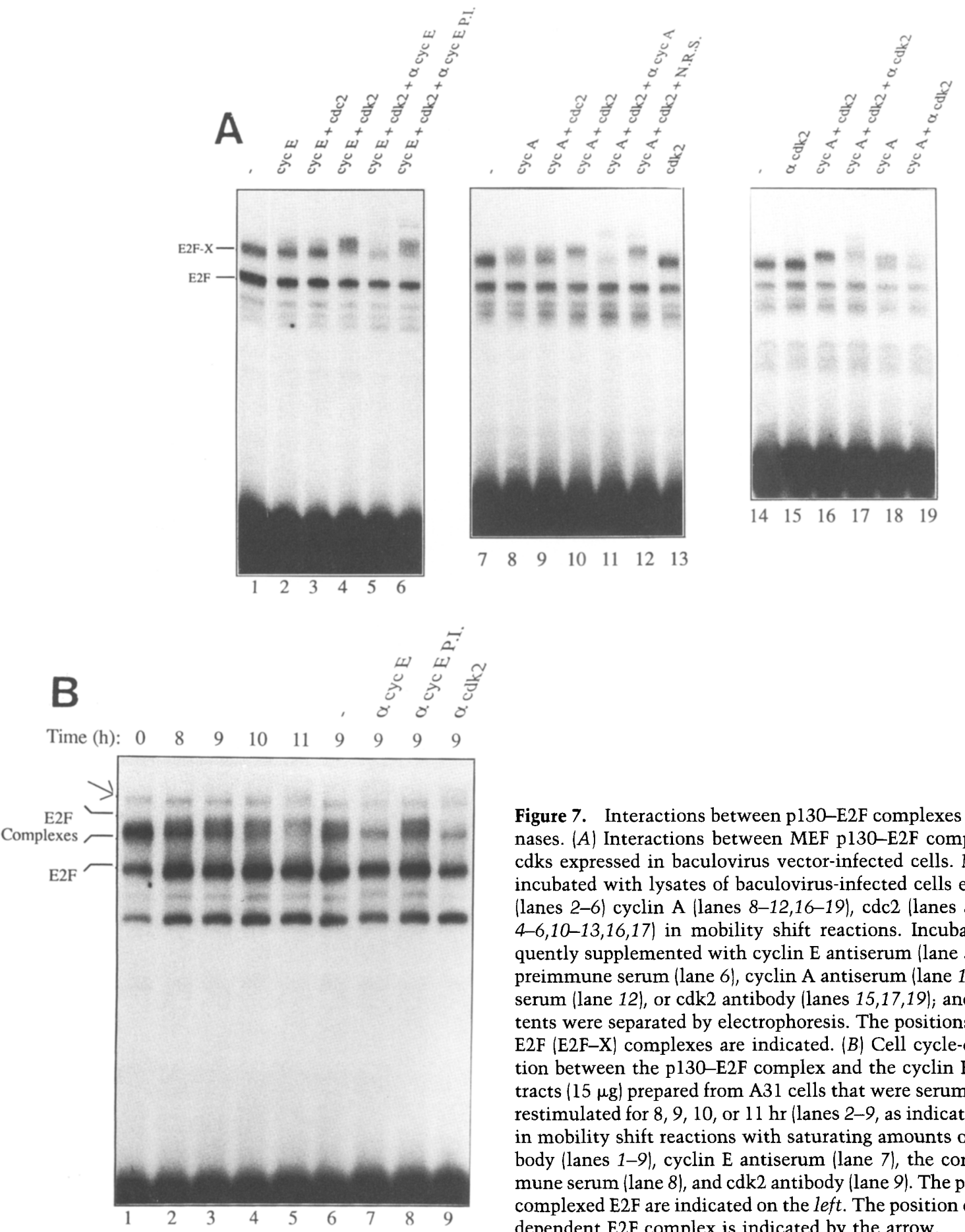

Figure 7. Interactions between p130-E2F complexes and cyclin-cdk kinases. (A) Interactions between MEF p130-E2F complexes and cyclincdks expressed in baculovirus vector-infected cells. MEF extracts were incubated with lysates of baculovirus-infected cells expressing cyclin $\mathrm{E}$ (lanes 2-6) cyclin A (lanes 8-12,16-19), cdc2 (lanes 3,9) or cdk2 (lanes 4-6,10-13,16,17) in mobility shift reactions. Incubations were subsequently supplemented with cyclin E antiserum (lane 5), a corresponding preimmune serum (lane 6), cyclin A antiserum (lane 11), a normal rabbit serum (lane 12), or cdk2 antibody (lanes 15,17,19); and the reaction contents were separated by electrophoresis. The positions of E2F and $\mathrm{pl} 30$ E2F (E2F-X) complexes are indicated. (B) Cell cycle-dependent interaction between the p130-E2F complex and the cyclin E-cdk2 kinase. Extracts $(15 \mu \mathrm{g})$ prepared from A31 cells that were serum-starved (lane 1) or restimulated for $8,9,10$, or $11 \mathrm{hr}$ (lanes $2-9$, as indicated) were incubated in mobility shift reactions with saturating amounts of SD-15 p107 antibody (lanes 1-9), cyclin E antiserum (lane 7), the corresponding preimmune serum (lane 8), and cdk2 antibody (lane 9). The positions of free and complexed E2F are indicated on the left. The position of a p107 antibodydependent E2F complex is indicated by the arrow.

These higher order complexes are dependent on the presence of both the cyclin and cdk subunit, similar to the association of cyclin-cdks with p107 or a $G_{1}$ E2F complex (Peeper et al. 1993; Schwarz et al. 1993).

Because cyclin $\mathrm{E}$ is first found in substantial amounts in the late $G_{1}$ phase of the cell cycle (Lew et al. 1991), when slowly migrating E2F complexes lacking p107 appear, we tested whether these late $G_{1}$ complexes contain cyclin $\mathrm{E}$ and cdk2. As shown in Figure $7 \mathrm{~B}$, slowly migrating E2F complexes that were resistant to saturating amounts of p107 antibody were formed from 8 to $11 \mathrm{hr}$ after serum stimulation (lanes 1-5). We found that antiserum directed against cyclin $\mathrm{E}$ disrupted the complexes detected $9 \mathrm{hr}$ after serum stimulation, whereas the corresponding preimmune serum had no effect (lanes 6-8). Similarly, anti-cdk2 antibody selectively disrupted this slowly migrating species (lane 9).

These results indicate that E2F and its associated p130 protein not only form higher order complexes with exogenous, baculovirus-expressed cyclins and cdks but also 
form such higher order complexes with cyclins and cdks expressed in late $G_{1}$ cells. Importantly, the present experiments do not indicate whether these complexes are actually present throughout late $G_{1}$. Thus, such quaternary complexes might only form in the narrow window of time after the induction of high levels of cyclin $\mathrm{E}$ expression and before p107 becomes the predominant E2F-associated protein.

\section{Discussion}

The abilities of pRb and pl07 to bind E2F transcription factors and to inhibit the expression of E2F-dependent genes suggested that these E2F interactions play important roles in cell growth control (Nevins 1992). Here, we show that E2Fs are also bound by the p130 protein. p130 was discovered as a prominent E1A-associated cellular protein (Harlow et al. 1986), and has recently been found to be structurally related to $\mathrm{pRb}$ and p107 (Hannon et al., Li et al., both this issue). Our present finding that p130 binds to E2Fs indicates that p130 also has functional analogies with $\mathrm{pRb}$ and $\mathrm{p} 107$.

The mobility shift and affinity enrichment procedures used here demonstrate that p130 is the major E2F-associated protein in $G_{0}$ A31 fibroblasts. pl30 also appeared to be the major E2F-associated protein in $G_{1}$ fibroblasts that were released from serum starvation, whereas only small amounts of pRb and p107 associated with E2Fs in extracts prepared from these serum-starved or restimulated cells. In a related study, Chittenden et al. (1993) have found that the major E2F complex in quiescent and stimulated $\mathrm{G}_{1}$ lymphocytes appears to contain neither $\mathrm{pRb}$ nor p107. Thus, p130 may be a component of the major $\mathrm{G}_{0} / \mathrm{G}_{1}$ E2F complex in lymphocytes, as well as in fibroblasts. However, pRb, p107, and p130 were associated with E2Fs in comparable amounts in other types of serum-starved cells, such as $\mathrm{HaCaT}$ keratinocytes.

The different patterns of E2F-associated proteins observed in these serum-starved cell types could reflect cell type-specific differences in the expression of the various E2Fs or the pRb-related E2F partners (Bernards et al. 1989; Helin et al. 1992; Szekely et al. 1992; Slack et al. 1993). Alternatively because nearly $100 \%$ of our serumstarved A31 cells were in the $G_{0} / G_{1}$ phase of the cell cycle, whereas only $94 \%$ of $\mathrm{HaCaT}$ cells were in $\mathrm{G}_{0} / \mathrm{G}_{1}$ after a much longer period of serum starvation (data not shown), p130 may become the predominant regulator of E2F only in cells that are effectively growth-arrested in $\mathrm{G}_{\mathrm{O}}$ in response to mitogen deprivation.

Despite our finding that p130 is the predominant E2F partner in mouse fibroblasts, p130 might not regulate all E2Fs present in such cells. This is because the DNAbinding activity termed E2F is composed of a group of distinct polypeptides (Helin et al. 1992; Kaelin et al. 1992; Girling et al. 1993; Huber et al. 1993; Lees et al. 1993) that may each associate specifically with only a subset of the three $\mathrm{pRb}$-related proteins. Such a notion is supported by the recent finding that $\mathrm{pRb}$ and $\mathrm{pl} 107$ associate with different forms of E2Fs (Dyson et al. 1993) and by evidence of apparently distinct species of E2Fs in cer- tain lymphocyte multiprotein complexes (Chittenden et al. 1993). The ability of E2F family members to interact with distinct $\mathrm{pRb}$-related regulators may allow the various E2F subtypes and E2F-responsive genes to be controlled independently during the cell cycle. In this context, two or three pRb-related proteins might be required concurrently for normal E2F regulation.

Of the three E2F-associated proteins, p107 and p130 are by far the most closely related (Hannon et al., Li et al., both this issue). This raises the possibility that p107 and p130 interact with the same E2F species and that the dramatic increase in E2F-associated pl07 near the $G_{1} / S$ border results primarily from a similarly dramatic increase in p107 protein levels shown here. The distinct cell cycle-dependent patterns of E2F association exhibited by p130 and p107, however, could also reflect the availability of specific E2Fs with which p130 and p107 interact, or processes that regulate the expression or the E2F-binding capability of p130.

Regardless of the specific E2F subtypes with which p130 and p107 interact, our data and that of others indicate that E2F complexes containing either of these proteins can associate with cyclinE-cdk2 and cyclin A-cdk2 kinases. Although the function of the cyclincdk2-containing higher order E2F complexes is not known as yet, the similarities between p130 and p107 suggest that p130- and p107-containing complexes may serve the same function, despite their differential regulation during the cell cycle. Higher order p107-containing complexes were detected previously in late $\mathrm{G}_{1}$ - and S-phase cell extracts (Cao et al. 1992; Devoto et al. 1992; Lees et al. 1992; Shirodkar et al. 1992), and we demonstrate here that p130-E2F-cyclin E-cdk2 complexes form in late $G_{1}$ before the induction of high levels of p107. Our data suggest that higher order complexes containing p130 or p107 may be present in cells continuously from late $G_{1}$ into $S$ phase.

Others have shown that mutant forms of the E1A oncoprotein that bind $\mathrm{pRb}$ and $\mathrm{p} 107$, but are severely impaired in p130 binding, exhibit a reduced ability to transform primary cells in cooperation with an activated ras oncogene (Whyte et al. 1988; Giordano et al. 1991). This suggests that p130 plays an important role in the regulation of cell proliferation and, further, that it may function as a suppressor of cell transformation. The present results provide one mechanistic explanation of how p130 may participate in such control. By regulating E2F function, p130 may indirectly control the expression of critical E2F-responsive genes in $G_{0}$ and early $G_{1}$ and in this way program early steps in the cell growth cycle. For other E2F-responsive genes, or in other cell growth stages, such control may be exerted by the p130 cognates $\mathrm{pRb}$ and $\mathrm{p} 107$, in this way ensuring an orderly regulation of the transcription of cell growth-promoting genes.

\section{Materials and methods}

Cells and cell culture

MEFs were prepared from 12.5-day wild-type and $\mathrm{Rb}^{-}$mouse embryos (Jacks et al. 1992) as described (Robertson 1987). Early 
passage A31 BALB/c 3T3 cells were obtained from C. Stiles (Dana Farber Cancer Center, Boston, MA). HEK and 293 cells were obtained from A. Van der Eb. HER cells were provided by A. Van der Eb and by D. Alberts (Massachusetts General Hospital, Boston, MA). HaCaT cells (Boukamp et al. 1988) were a gift from P. Boukamp. SiFt fibroblasts were obtained from J. Rheinwold. U937 cells were from J. Minowada (Roswell Park Memorial Institute, Buffalo, NY). Mouse splenic lymphocytes were prepared from freshly dissected spleens.

MEFs were grown in Dulbecco's modified Eagle medium (DMEM, GIBCO) with $10 \%$ fetal calf serum (FCS, Hyclone Laboratories). A31 and 293 cells were grown in DMEM with 10\% calf serum (CS, GIBCO). SiFt, HER, and HEK cells were grown in DMEM with $15 \%$ FCS (GIBCO). HaCaT cells were grown in $\alpha$ minimal essential medium ( $\alpha$ MEM, GIBCO) with $10 \%$ FCS. U937 cells were grown in RPMI (GIBCO) with $10 \%$ FCS.

\section{Cell synchronization}

MEF and A31 cells were plated at $7.5 \times 10^{5}$ cells per $10-\mathrm{cm}$ -diam. culture dish, allowed to grow for $24 \mathrm{hr}$, and then incubated in DMEM plus $0.5 \%$ serum for 54 or $44 \mathrm{hr}$, respectively. All other cells were plated at $1 \times 10^{6}$ cells per $10-\mathrm{cm}$ dish, allowed to grow for $48 \mathrm{hr}$, and incubated in $\alpha M E M$ for $72 \mathrm{hr}$ ( $\mathrm{HaCaT}$ cells) or in DME plus $0.5 \%$ FCS for $48 \mathrm{hr}$ ( $\mathrm{SiFt}$, HEK, and HER cells).

\section{Metabolic labeling}

Cells were grown for $20 \mathrm{~min}$ in methionine-free DMEM (GIBCO) plus $0.5 \%$ or $10 \%$ dialyzed CS or FCS /depending on the cell type and desired growth conditions), followed by incubation in medium containing $0.15-0.3 \mathrm{mCi} / \mathrm{ml}$ of Trans ${ }^{35} \mathrm{~S}-\mathrm{la}$ bel (ICN) for $6 \mathrm{hr}$ unless otherwise indicated.

\section{Extract preparation}

Whole cell extracts were prepared from trypsinized cells at $4^{\circ} \mathrm{C}$. Cells were suspended in DMEM plus $10 \%$ CS, washed in phosphate-buffered saline [PBS, $137 \mathrm{mM} \mathrm{NaCl}, 2.7 \mathrm{~mm} \mathrm{KCl}, 10 \mathrm{~mm}$ $\mathrm{NaPO}_{4}$ (pH 7.0)], resuspended in 5 packed cell volumes of buffer A [10 mM HEPES ( $\mathrm{pH} 7.9$ ), $1.5 \mathrm{~mm} \mathrm{MgCl}_{2}, 10 \mathrm{~mm} \mathrm{KCl}, 0.5 \mathrm{~mm}$ dithiothreitol (DTT), and protease and phosphatase inhibitors $(1$ mM phenylmethylsulfonyl fluoride, $1 \mu \mathrm{g} / \mathrm{ml}$ of leupeptin, $2 \mu \mathrm{g} /$ $\mathrm{ml}$ of aprotinin, $1 \mathrm{~mm}$ sodium orthovanadate)], pelleted in an Eppendorf centrifuge at $6000 \mathrm{rpm}$, resuspended in 3 packed cell volumes of buffer A, homogenized in a Dounce apparatus using 100 strokes of the A pestle, and centrifuged at 14,000 rpm for 5 min. The supernatant (cytoplasmic extract) was removed and the pellet was suspended in 2 volumes of buffer A [but containing $0.4 \mathrm{M} \mathrm{NaCl}, 25 \%$ glycerol, and HEPES (pH 7.9) at $20 \mathrm{mM}$ ), incubated with mixing for $30 \mathrm{~min}$, and centrifuged at 14,000 $\mathrm{rpm}$ for $5 \mathrm{~min}$. The supernatant (nuclear extract) was combined with the cytoplasmic extract, centrifuged at $14,000 \mathrm{rpm}$ for 1 min, and stored at $-80^{\circ} \mathrm{C}$.

Cell lysates used for immunoprecipitations were prepared by washing cells with PBS, incubating in $1 \times \mathrm{ELB}[0.25 \mathrm{M} \mathrm{NaCl}$, $0.1 \%$ NP-40, $25 \mathrm{~mm}$ HEPES (pH 7.0), $2.5 \mathrm{~mm}$ EDTA, $0.5 \mathrm{~mm}$ DTT, and inhibitors as above] with mixing on ice for $30 \mathrm{~min}$, and centrifuging at $14,000 \mathrm{rpm}$ for $5 \mathrm{~min}$.

\section{Mobility shift assays}

Mobility shift assays (Kovesdi et al. 1986) utilized a gel-purified, ${ }^{32} \mathrm{P}$-end-labeled double-stranded oligonucleotide probe of plus strand sequence: 5'-GGCTTCTCAGAGGCTTGGCGGGAA-
AAAGAACGGAGGGAGGGAT-3', representing the -82 to -40 sequence of the human c-myc P2 promoter. Cell extracts were incubated for $20 \mathrm{~min}$ at room temperature in $10-\mu \mathrm{l}$ reactions containing $60 \mu \mathrm{g} / \mathrm{ml}$ of boiled and sonicated salmon sperm (SS) DNA, $20 \mathrm{~mm}$ HEPES (pH 7.6), 4\% Ficoll, $2.5 \mathrm{~mm}$ $\mathrm{MgCl}_{2}, 40 \mathrm{~mm} \mathrm{KCl}, 0.1 \mathrm{~mm}$ EGTA, $0.5 \mathrm{mg} / \mathrm{ml}$ of acetylated bovine serum albumin (BSA, New England Biolabs) $0.5 \mathrm{~mm}$ DTT, and $0.5 \mathrm{pmol} / \mathrm{ml}$ of probe, followed by electrophoresis in a $4 \%$ polyacrylamide gel in $22 \mathrm{~mm}$ Tris, $22 \mathrm{~mm}$ boric acid, and $0.6 \mathrm{mM}$ EDTA.

Competitive binding reactions included a 20 -fold molar excess of an unlabeled double-stranded oligonucleotide containing nucleotides -71 to -27 of the adenovirus E2 promoter and flanked by unrelated restriction sites of sequence 5 '-CGCGTGGATCCAGTTTTCGCGCTTAAATTTGAGAAAGGGCGCGAAACTAGTCCTTAC- $3^{\prime}$ for the plus strand. The corresponding point-mutated oligonucleotide substituted the underlined $C$ residue with $A$ and substituted the underlined $G$ residue with $T$ (Hiebert et al. 1989).

\section{Protein preparations}

Purified $\mathrm{pRb}$ and cell lysates containing cyclin A, cyclin B, cyclin $\mathrm{E}$, cdk2, and cdc2 were prepared from insect cells infected with the corresponding recombinant baculoviruses as described (Desai et al. 1992; Dowdy et al. 1993; S. Mittnacht and S.F. Dowdy, unpubl.). E1A was prepared from baculovirus-infected insect cells (Peeper et al. 1992) by lysis in 2 packed cell volumes of $1 \times$ ELB for $15 \mathrm{~min}$. E2F was affinity purified as described (Yee et al. 1989).

\section{Antibodies}

p107 monoclonal antibody (SD-6, SD-9, and SD-15) hybridoma tissue culture supernatants (Dyson et al. 1993) were generously provided by M. Dembski and N. Dyson. Affinity-purified cdk-2 monoclonal antibody (Tsai et al. 1993) was a gift of L.-H. Tsai and E. Harlow. Cyclin E rabbit antiserum and preimmune serum (Dulic et al. 1992) were generously provided by V. Dulic and S. Reed. Cyclin A rabbit antiserum (Pines and Hunter 1990) was the kind gift of J. Pines and T. Hunter. Normal rabbit serum and rabbit anti-mouse IgG were from Sigma. E1A monoclonal antibody M73 (Harlow et al. 1985) was an ascites preparation. $\mathrm{pRb}$ monoclonal antibody 21C9 (Templeton and Weinberg 1991) was a hybridoma tissue culture supernatant, and pRb monoclonal antibody G3-245 were from PharMingen. p130 monoclonal antibody $\mathrm{Z} 11$ (Li et al., this issue) was a hybridoma tissue culture supernatant.

The p107 SD-15 antibody used in mobility shift experiments was purified by using an anti-mouse IgG column (Sigma) as described (Harlow and Lane 1988), and the antibody was concentrated using a microcon apparatus (Amicon). In titration experiments utilizing $G_{0^{-}}$and S-phase whole cell extracts, halfmaximal supershifting of p107-containing complexes was obtained with $25 \mathrm{ng}$ of purified antibody, and maximum supershifting was obtained with $75 \mathrm{ng}$ (data not shown). To each mobility shift reaction $225 \mathrm{ng}$ of antibody was added to ensure saturation binding to p107.

\section{Affinity chromatography}

The herring sperm DNA column was prepared by linking sheared herring sperm DNA (Sigma) to Affi-gel 10 (Bio-Rad Laboratories). Oligonucleotide columns were prepared as described (Kadonaga and Tjian 1986) using CNBr-activated Sepharose 4B (Pharmacia). The E2 oligonucleotide column consisted of mul- 
timers of sequences from -26 to -81 of the adenovirus 5 E2 promoter (Imperiale and Nevins 1984) flanked by HindIII overhangs: 5'-AGCTTGAGATGACGTAGTTTTCGCGCTTAAATTTGAGAAAGGGCGCGAAACTAGTCCTTA- 3 ' on the plus strand. The wild-type and mutant E2F site oligonucleotide columns were prepared in parallel and contained nearly identical amounts of multimerized oligonucleotide of sequences from -53 to -72 of the adenovirus 5 E2 promoter and flanked by HindIII overhangs: 5'-AGCTAGTTTTCGCGCTTAAATTT-3' and 5 '-AGCTAGTTTCGAGCTTAAATTT- ${ }^{\prime}$ ' for the plus strands of the wild-type and mutant columns, respectively.

Chromatography was performed using $0.5-0.8 \mathrm{ml}$ of whole cell extract brought to $0.1 \% \mathrm{NP}-40$ and $600 \mu \mathrm{g} / \mathrm{ml}$ of boiled and sonicated salmon sperm DNA that had been passed 20 times through 23-gauge and then 27-gauge needles. The solution was stored on ice for $15 \mathrm{~min}$ and then loaded onto a $0.5-\mathrm{ml}$ herring sperm DNA column equilibrated with buffer $\mathrm{C}[0.1 \mathrm{M} \mathrm{KCl}, 20$ mM HEPES (pH 7.6), 0.2 mM EGTA, $2 \mathrm{~mm} \mathrm{MgCl}_{2}, 0.1 \%$ NP-40, $0.5 \mathrm{mM}$ DTT, and inhibitors as above]. The peak flow-through fraction of $1.3 \times$ the load volume was collected, the column was washed with 5 volumes of buffer $C$, and then eluted with $2 \times$ ELB [0.5 M NaCl, 0.2\% NP-40, $50 \mathrm{~mm}$ HEPES (pH 7.0), $5 \mathrm{~mm}$ EDTA, $0.5 \mathrm{~mm}$ DTT, and inhibitors as above], initiating collection of $0.7-\mathrm{ml}$ elution fractions after loading 0.5 column volumes of $2 \times$ ELB. The same procedure was used for chromatography of the herring sperm DNA column flowthrough fraction over oligonucleotide columns. The protein radioactivity content of elution fractions was determined by trichloracetic acid precipitation. Elution fractions were brought to $0.1 \mathrm{mg} / \mathrm{ml}$ of BSA before storing at $-80^{\circ} \mathrm{C}$, and were brought to $250 \mathrm{mM} \mathrm{NaCl}$ by mixing with 0.33 volumes of $\mathrm{H}_{2} \mathrm{O}$ before use in immunoprecipitation experiments.

\section{Immunoprecipitations}

E1A coimmunoprecipitations were performed by mixing affinity column eluates $\left(0.5 \times 10^{6}\right.$ to $2.0 \times 10^{6} \mathrm{cpm}$ of radiolabeled protein) with $2 \mu \mathrm{l}$ of ElA or control lysate, $30 \mu \mathrm{l}$ of a $10 \%$ solution of zysorbin (Zymed Laboratories), and $1 \times$ ELB added to $0.6 \mathrm{ml}$. Solutions were mixed for $30 \mathrm{~min}$ at $4^{\circ} \mathrm{C}$ and centrifuged. The supernatants were added to $1 \mu l$ of M73 anti-E1A or control ascites, kept on ice for $1 \mathrm{hr}$, mixed with protein A-agarose (BioRad Laboratories) for $1 \mathrm{hr}$, and the protein A-agarose was then washed four times in $1 \times$ ELB and prepared for electrophoresis in $6 \%$ SDS-polyacrylamide gels and fluorography (Harlow and Lane 1988). pRb and p107 were immunoprecipitated using a combination of $100 \mu \mathrm{l}$ of $21 \mathrm{C} 9$ and $3 \mu \mathrm{l}$ of G3-245 for $\mathrm{pRb}$ and a combination of $50 \mu \mathrm{l}$ each of SD-6, SD-9, and SD-15 for pl07.

\section{Western analysis}

${ }^{35} \mathrm{~S}$-Labeled HaCaT whole cell extract $(0.5 \mathrm{ml})$ and unlabeled extract $(3.0 \mathrm{ml})$ were prepared in parallel, combined, divided into four fractions of $2.75 \mathrm{mg}$, and chromatographed over four 0.75 $\mathrm{ml}$ herring sperm DNA columns, and the flowthrough fractions were chromatographed over $0.75-\mathrm{ml}$ E2 oligonucleotide columns. The elution fractions from each E2 column were combined, brought to $0.25 \mathrm{M} \mathrm{NaCl}$, divided into four equal fractions, and coimmunoprecipitated with ElA. Precipitated proteins were electrophoretically separated and transferred to a nitrocellulose membrane. A portion of the membrane was directly autoradiographed. The remaining membrane was incubated at $23^{\circ} \mathrm{C}$ in $0.05 \%$ Tween-20 in PBS (TPBS) containing $5 \%$ dried milk for $30 \mathrm{~min}$ and in Z11 p130 antibody diluted $0.1 \times$ in TPBS containing $2.5 \%$ dried milk for $10 \mathrm{hr}$, and was then washed and detected using horseradish peroxidase-linked rabbit antimouse IgG and an enhanced chemiluminescence kit (Amersham).

The p107 Western blot utilized $5 \mathrm{mg}$ of A31 cell extract that was immunoprecipitated with a cocktail of p107 antibodies as described above, and subjected to Western analysis, using SD-9 as the primary antibody.

\section{Peptide mapping}

E2 column eluate $\left(1.5 \times 10^{7} \mathrm{cpm}\right)$ was coimmunoprecipitated with E1A and loaded into each of three lanes before separation in a $6 \%$ polyacrylamide gel. Gels were exposed to film for $48 \mathrm{hr}$, and protein bands were excised, treated with the indicated amounts of porcine trypsin 1:250 (Sigma) during electrophoresis (Cleveland et al. 1977), separated in a $16.5 \%$ SDS-polyacrylamide gel, and prepared for fluorography.

\section{Acknowledgements}

We thank M. Dembski, N. Dyson, L.-H. Tsai, E. Harlow, V. Dulic, S. Reed, J. Pines, T. Hunter, K. Louie, and S. Mittnacht for antibodies; D. Morgan, S.F. Dowdy, and S. Mittnacht for recombinant baculoviruses, R. Goldsby for mouse splenocytes, and $\mathrm{D}$. Templeton for the herring sperm DNA column. We also thank K. Brose and S. Connor for performing flow cytometry analyses, members of the Weinberg laboratory for helpful discussions, and S. F. Dowdy and T. Makela for critical reading of the manuscript. This work was supported in part by National Institutes of Health grants R35 CA39826 (R.A.W.) and 5P01 CA42063 (T.J.) and by a career award and grant 2742 from the National Cancer Institute of Canada (P.W.). D.C. was supported by postdoctoral fellowships from the American Cancer Society and the Susan G. Komen Breast Cancer Foundation. D.S.P. was supported by the Dutch Cancer Society. T.J. is a Lucille P. Markey Scholar. R.A.W. is an American Cancer Society Research Professor.

The publication costs of this article were defrayed in part by payment of page charges. This article must therefore be hereby marked "advertisement" in accordance with 18 USC section 1734 solely to indicate this fact.

\section{References}

Bagchi, S., P. Raychaudhuri, and J.R. Nevins. 1990. Adenovirus E1A proteins can dissociate heteromeric complexes involving the E2F transcription factor: A novel mechanism for E1A trans-activation. Cell 62: 659-669.

Bagchi, S., R. Weinmann, and P. Raychaudhuri. 1991. The retinoblastoma protein copurifies with E2F-I, an E1A-regulated inhibitor of the transcription factor E2F. Cell 65: 1063-1072.

Bernards, R., G.M. Shackleford, M.R. Gerber, J.M. Horowitz, S.H. Friend, M. Schartl, E. Bogenmann, J.M. Rapaport, T. McGee, T.P. Dryja, and R.A. Weinberg. 1989. Structure and expression of the murine retinoblastoma gene and characterization of its encoded protein. Proc. Natl. Acad. Sci. 86: 6474-6478.

Blake, M.C. and J.C. Azizkhan. 1989. Transcription factor E2F is required for efficient expression of the hamster dihydrofolate reductase gene in vitro and in vivo. Mol. Cell. Biol. 9: 4994 5002.

Boukamp, P., R.T. Petrussevska, D. Breitkreutz, J. Hornung, A. Markham, and N.E. Fusenig. 1988. Normal keratinization in a spontaneously immortalized aneuploid human keratinocyte cell line. I. Cell Biol. 106: 761-771.

Buchkovich, K., L.A. Duffy, and E. Harlow. 1989. The retino- 
blastoma protein is phosphorylated during specific phases of the cell cycle. Cell 58: 1097-1105.

Cao, L., B. Faha, M. Dembski, L.-H. Tsai, E. Harlow, and N. Dyson. 1992. Independent binding of the retinoblastoma protein and p107 to the transcription factor E2F. Nature 355: 176-179.

Chellappan, S., V.B. Kraus, B. Kroger, K. Munger, P.M. Howley, W.C. Phelps, and J.R. Nevins. 1992. Adenovirus E1A, simian virus 40 tumor antigen, and human papillomavirus E7 protein share the capacity to disrupt the interaction between transcription factor E2F and the retinoblastoma gene product. Proc. Natl. Acad. Sci. 89: 4549-4593.

Chellappan, S.P., S. Hiebert, M. Mudryj, J.M. Horowitz, and J.R. Nevins. 1991. The E2F transcription factor is a cellular target for the RB protein. Cell 65: 1053-1061.

Chen, P.-L., P. Scully, J.-Y. Shew, J.Y.J. Wang, and W.-H. Lee. 1989. Phosphorylation of the retinoblastoma gene product is modulated during the cell cycle and cellular differentiation. Cell 58: 1193-1198.

Chittenden, T., D.M. Livingston, and J.A. DeCaprio. 1993. Cell cycle analysis of $E 2 F$ in primary human $T$ cells reveals novel E2F complexes and biochemically distinct forms of free E2F. Mol. Cell. Biol. 13: 3975-3983.

Cleveland, D.W., S.G. Fischer, M.W. Kirschner, and U.K. Laemmli. 1977. Peptide mapping by limited proteolysis in sodium dodecyl sulfate and analysis by gel electrophoresis. J. Biol. Chem. 252: 1102-1106.

Dalton, S. 1992. Cell cycle regulation of the human $c d c 2$ gene. EMBO J. 11: 1797-1804.

DeCaprio, J.A., J.W. Ludlow, D. Lynch, Y. Furukawa, J. Griffin, H. Piwnica-Worms, C.-M. Huang, and D.M. Livingston. 1989. The product of the retinoblastoma susceptibility gene has properties of a cell cycle regulatory element. Cell 58: 1085-1095.

Desai, D., Y. Gu, and D.O. Morgan. 1992. Activation of human cyclin-dependent kinases in vitro. Mol. Biol. Cell 3: 571582.

Devoto, S.H., M. Mudryi, J. Pines, T. Hunter, and J.R. Nevins. 1992. A cyclin A-protein kinase complex possesses sequence-specific DNA-binding activity: $\mathrm{p} 33 \mathrm{cdk} 2$ is a component of the E2F-cyclin A complex. Cell 68: 167-176.

Dowdy, S.F., P.W. Hinds, K. Louie, S.I. Reed, A. Arnold, and R.A. Weinberg. 1993. Physical interaction of the retinoblastoma protein with human D cyclins. Cell 73: 499-511.

Dulic, V., E. Lees, and S.I. Reed. 1992. Association of human cyclin $\mathrm{E}$ with a periodic G1-S-phase protein kinase. Science 257: 1958-1961.

Dyson, N., M. Dembski, A. Fattaey, C. Ngwu, M. Ewen, and K. Helin. 1993. Analysis of p107-associated proteins: p107 associates with a form of E2F that differs from $\mathrm{pRB}$-associated E2F-1. I. Virol. in press.

Ewen, M.E., Y. Xing, J.B. Lawrence, and D.M. Livingston. 1991. Molecular cloning, chromosomal mapping, and expression of the cDNA for p107, a retinoblastoma gene product-related protein. Cell 66: 1155-1164.

Farnham, P.J. and R.T. Schimke. 1985. Transcriptional regulation of mouse dihydrofolate reductase in the cell cycle. $J$. Biol. Chem. 260: 7675-7680.

Giordano, A., C. McCall, P. Whyte, and B.R. Franza. 1991. Human cyclin $A$ and the retinoblastoma protein interact with similar but distinguishable sequences in the adenovirus E1A gene product. Oncogene 6: 481-485.

Girling, R., J.F. Partridge, L.R. Bandara, N. Burden, N.F. Totty, J.J. Hsuan, and N.B. LaThangue. 1993. A new component of the transcription factor DRTF1/E2F. Nature 362: 83-87.

Hamel, P.A., R.M. Gill, R.A. Phillips, and B.L. Gallie. 1992.
Transcriptional repression of the E2-containing promoters $\mathrm{EIIaE}$, c-myc, and RB1 by the product of the RB1 gene. Mol. Cell. Biol. 12: 3431-3438.

Harlow, E., B.R. Franza, and C. Schley. 1985. Monoclonal antibodies specific for adenovirus early region $1 \mathrm{~A}$ proteins: Extensive heterogeneity in early region 1A products. J. Virol. 55: 533-546.

Harlow, E., P. Whyte, B.J. Franza, and C. Schley. 1986. Association of adenovirus early-region 1A proteins with cellular polypeptides. Mol. Cell. Biol. 6: 1579-1589.

Harlow, E., and D. Lane. 1988. Antibodies: A laboratory manual. Cold Spring Harbor Laboratory, Cold Spring Harbor, New York.

Helin, K., J.A. Lees, M. Vidal, N. Dyson, E. Harlow, and A. Fattaey. 1992. A cDNA encoding a pRB-binding protein with properties of the transcription factor E2F. Cell 70: 337-350.

Helin, K., C.-L. Wu, A.R. Fattaey, J.A. Lees, B.D. Dynlacht, C. Ngwu, and E. Harlow. 1993. Heterodimerization of the transcription factors E2F-1 and DP-1 leads to cooperative transactivation. Genes \& Dev. : 1850-1861.

Hiebert, S.W., S.P. Chellappan, J.M. Horowitz, and J.R. Nevins. 1992. The interaction of RB with E2F coincides with an inhibition of the transcriptional activity of E2F. Genes \& Dev. 6: $177-185$.

Hiebert, S.W., M. Lipp, and J.R. Nevins. 1989. ElA-dependent trans-activation of the human myc promoter is mediated by the E2F factor. Proc. Natl. Acad. Sci. 86: 3594-3598.

Huber, H.E., G. Edwards, P.J. Goodhart, D.R. Patrick, P.S. Huang, M. Ivey-Hoyle, S.F. Barnett, A. Oliff, and D.C. Heimbrook. 1993. Transcription factor E2F binds DNA as a heterodimer. Proc. Natl. Acad. Sci. 90: 3525-2539.

Imperiale, M.J. and J.R. Nevins. 1984. Adenovirus 5 E2 transcription unit: An ElA-inducible promoter with an essential element that functions independently of position or orientation. Mol. Cell. Biol. 4: 875-882.

Jacks, T., A. Fazeli, E.M. Schmitt, R.T. Bronson, M.A. Goodell, and R.A. Weinberg. 1992. Effects of an Rb mutation in the mouse. Nature 359: 295-300.

Kadonaga, J.T. and R. Tjian. 1986. Affinity purification of sequence-specific DNA binding proteins. Proc. Natl. Acad. Sci. 83: 5889-5893.

Kaelin, W.G., W. Krek, W.R. Sellers, J.A. DeCaprio, F. Ajchenbaum, C.S. Fuchs, T. Chittenden, Y. Li, P.J. Farnham, M.A. Blanar, D.M. Livingston, and E.K. Flemington. 1992. Expression cloning of a cDNA encoding a retinoblastoma-binding protein with E2F-like properties. Cell 70: 351-364.

Kelly, K., B.H. Cochran, C.D. Stiles, and P. Leder. 1983. Cell specific regulation of the c-myc gene by lymphocyte mitogens and platelet-derived growth factor. Cell 35: 603-610.

Kovesdi, I., R. Reichel, and J.R. Nevins. 1986. Identification of a cellular transcription factor involved in E1A trans-activation. Cell 45: 219-228.

Lam, E.W. and R.J. Watson. 1993. An E2F-binding site mediates cell-cycle regulated repression of mouse B-myb transcription. EMBO J. 12: 2705-2713.

Lees, E., B. Faha, V. Dulic, S.I. Reed, and E. Harlow. 1992. Cyclin $\mathrm{E} / \mathrm{cdk} 2$ and cyclin $\mathrm{A} / \mathrm{cdk} 2$ kinases associate with pl07 and E2F in a temporally distinct manner. Genes \& Dev. 6: 1874 1885.

Lees, J., M. Saito, M. Vidal, M. Valentino, T. Look, E. Harlow, N. Dyson, and K. Helin. 1993. The retinoblastoma protein binds to a family of E2F transcription factors. Mol. Cell. Biol. in press.

Lew, D.J., V. Dulic, and S.I. Reed. 1991. Isolation of three novel human cyclins by rescue of $\mathrm{Gl}$ cyclin $(\mathrm{Cln})$ function in yeast. Cell 66: 1197-1206. 
Mittnacht, S. and R.A. Weinberg. 1991. G1/S phosphorylation of the retinoblastoma protein is associated with an altered affinity for the nuclear compartment. Cell 65: 381-393.

Mudryi, M., S.H. Devoto, S.W. Hiebert, T. Hunter, J. Pines, and J.R. Nevins. 1991. Cell cycle regulation of the E2F transcription factor involves an interaction with cyclin A. Cell 65: 1243-1253.

Nevins, J.R. 1992. E2F: A link between the Rb tumor suppressor protein and viral oncoproteins. Science 258: 424-429.

Pagano, M., G. Draetta, and P. Jansen-Durr. 1992. Association of cdk2 kinase with the transcription factor E2F during S-phase. Science 255: 1144-1147.

Peeper, D.S., L.L. Parker, M.E. Ewen, M. Toebes, F.L. Hall, M. Xu, A. Zantema, A.J.v.d. Eb, and H. Piwnica-Worms. 1993. A- and B-type cyclins differentially modulate substrate specificity of cyclin-cdk complexes. EMBO I. 12: 1947-1954.

Peeper, D.S., A. Zantema, S.F. Dowdy, and A.J.v.d. Eb. 1992. Expression, purification, and functional characterization of adenovirus 5 and 12 ElA proteins produced in insect cells. Virology 190: 733-745.

Pines, I. and T. Hunter. 1990. Human cyclin A is adenovirus ElA-associated protein $\mathrm{p} 60$ and behaves differently from cyclin B. Nature 346: 760-763.

Robertson, E.J. 1987. Embryo-derived stem cell lines. In Teratocarcinomas and embryonic stem cells: A practical approach (ed. E. J. Robertson). IRL Press, Oxford, UK.

Schwarz, J.K., S.H. Devoto, E.J. Smith, S.P. Chellappan, L. Jakoi, and J.R. Nevins. 1993. Interactions of the p107 and Rb proteins with E2F during the cell proliferation response. EMBO J. 12: 1013-1020.

Shirodkar, S., M. Ewen, J.A. DeCaprio, J. Morgan, D.M. Morgan, and T. Chittenden. 1992. The transcription factor E2F interacts with the retinoblastoma product and a p107-cyclin A complex in a cell cycle-regulated manner. Cell 68: 157-166.

Slack, R.S., P.A. Hamel, T.S. Bladon, R.M. Gill, and M.W. McBurney. 1993. Regulated expression of the retinoblastoma gene in differentiating embryonal carcinoma cells. Oncogene 8: 1585-1591.

Szekely, L., W.-Q. Jiang, F. Bulic-Jakus, A. Rosen, N. Ringertz, G. Klein, and K.G. Wiman. 1992. Cell type and differentiation dependent heterogeneity in retinoblastoma protein expression in SCID mouse fetuses. Cell Growth Differ. 3: 149156.

Templeton, D. and R.A. Weinberg. 1991. Nonfunctional mutants of the retinoblastoma protein are characterized by defects in phosphorylation, viral oncoprotein association, and nuclear tethering. Proc. Natl. Acad. Sci. 88: 3033-3037.

Thalmeier, K., H. Synovzik, R. Mertz, E.-L. Winnacker, and M. Lipp. 1989. Nuclear factor E2F mediates basic transcription and trans-activation by ElA of the human myc promoter. Genes \& Dev. 3: 527-536.

Tsai, L.-H., E. Lees, B. Faha, E. Harlow, and K. Riabowol. 1993. The cdk2 kinase is required for the G1-to-S transition in mammalian cells. Oncogene 8: 1593-1602.

Weintraub, S.J., C.A. Prater, and D.C. Dean. 1992. Retinoblastoma protein switches the E2F site from positive to negative element. Nature 358: 259-261.

Whyte, P., H.E. Ruley, and E. Harlow. 1988. Two regions of the adenovirus early region $1 \mathrm{~A}$ proteins are required for transformation. J. Virol. 62: 257-265.

Yee, A., P. Raychaudhuri, L. Jakoi, and J.R. Nevins. 1989. The adenovirus-inducible factor E2F stimulates transcription after specific DNA binding. Mol. Cell. Biol. 9: 578-585.

Zamanian, M. and N.B. LaThangue. 1992. Adenovirus Ela prevents the retinoblastoma gene product from repressing the activity of a cellular transcription factor. EMBO I. 11: 2603-
2610.

1993. Transcriptional repression by the Rb-related protein p107. Mol. Biol. Cell 4: 389-396.

Zhu, L., S. van de Heuvel, K. Helin, A. Fattaey, M. Ewen, D. Livingston, N. Dyson, and E. Harlow. 1993. Inhibition of cell proliferation by p107, a relative of the retinoblastoma protein. Genes \& Dev. 7: 1111-1125. 


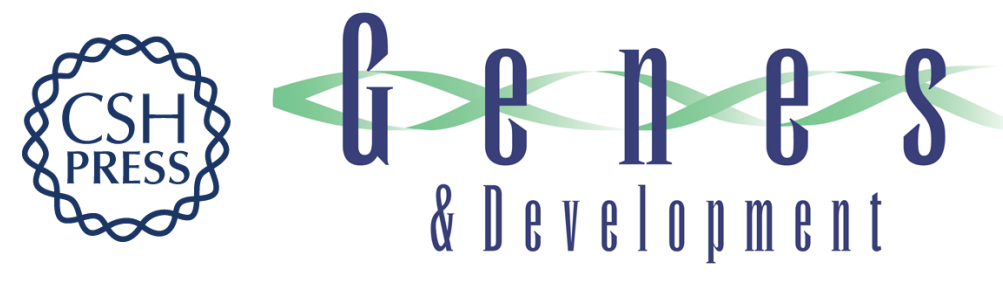

\section{Cell cycle-specific association of E2F with the p130 E1A-binding protein.}

D Cobrinik, P Whyte, D S Peeper, et al.

Genes Dev. 1993, 7:

Access the most recent version at doi:10.1101/gad.7.12a.2392

References This article cites 58 articles, 27 of which can be accessed free at: http://genesdev.cshlp.org/content/7/12a/2392.full.html\#ref-list-1

License

Email Alerting Receive free email alerts when new articles cite this article - sign up in the box at the top Service right corner of the article or click here.

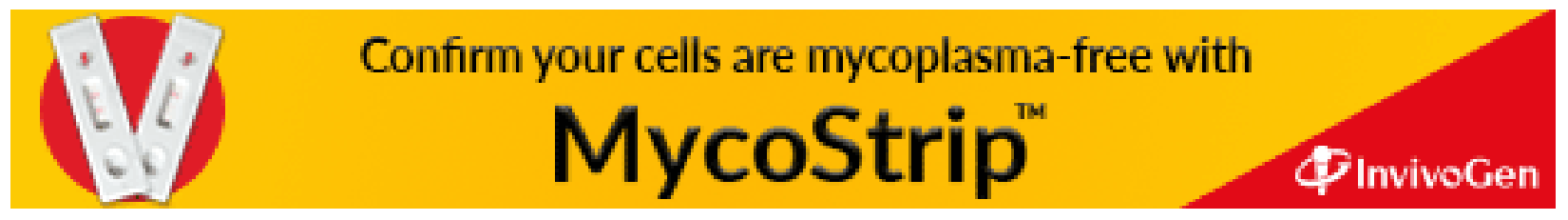

